Louisiana State University

LSU Digital Commons

Faculty Publications

Department of Geology and Geophysics

$1-1-1999$

\title{
Physical controls on the Taylor Valley ecosystem, Antarctica
}

Andrew G. Fountain

Portland State University

W. Berry Lyons

The University of Alabama

Melody B. Burkins

Dartmouth College

Gayle L. Dana

Desert Research Institute

Peter T. Doran

University of Illinois at Chicago

See next page for additional authors

Follow this and additional works at: https://digitalcommons.Isu.edu/geo_pubs

\section{Recommended Citation}

Fountain, A., Lyons, W., Burkins, M., Dana, G., Doran, P., Lewis, K., McKnight, D., Moorhead, D., Parsons, A., Priscu, J., Wall, D., Wharton, R., \& Virginia, R. (1999). Physical controls on the Taylor Valley ecosystem, Antarctica. BioScience, 49 (12), 961-971. https://doi.org/10.1525/bisi.1999.49.12.961

This Article is brought to you for free and open access by the Department of Geology and Geophysics at LSU Digital Commons. It has been accepted for inclusion in Faculty Publications by an authorized administrator of LSU Digital Commons. For more information, please contact ir@lsu.edu. 
Authors

Andrew G. Fountain, W. Berry Lyons, Melody B. Burkins, Gayle L. Dana, Peter T. Doran, Karen J. Lewis, Diane M. McKnight, Daryl L. Moorhead, Andrew N. Parsons, John C. Priscu, Diana H. Wall, Robert A. Wharton, and Ross A. Virginia 


\section{Physical Controls on the Taylor Valley Ecosystem, Antarctica}

ANDREW G. FOUNTAIN, W. BERRY LYONS, MELODY B. BURKINS, GAYLE L. DANA, PETER T. DORAN, KAREN J. LEWIS, DIANE M. MCKNIGHT, DARYL L. MOORHEAD, ANDREW N. PARSONS, JOHN C. PRISCU, DIANA H. WALL, ROBERT A. WHARTON JR., AND ROSS A. VIRGINIA

\section{M} ost of Antarctica is covered by ice that may exceed $3000 \mathrm{~m}$ in depth, but some areas of the continent are ice free. The McMurdo Dry Valleys, at $76^{\circ} 30^{\prime}-78^{\circ} 30^{\prime} \mathrm{S}, 160-164^{\circ} \mathrm{E}$, form the largest (approximately $4800 \mathrm{~km}^{2}$ ) of the ice-free areas. This location has also been a US National Science Foundation (NSF)-funded Long-Term Ecological Research (LTER) site since 1993. The dry valleys are among the most extreme deserts on the planet, far colder and drier than deserts elsewhere. Mean annual temperatures in Taylor Valley (primary location of the McMurdo LTER) range from $-16^{\circ} \mathrm{C}$ to $-21{ }^{\circ} \mathrm{C}$, and precipitation is less than $10 \mathrm{~cm}$ annually. The dry valleys contain perennially ice-covered lakes, ephemeral streams, glaciers, and extensive areas of both soils and exposed bedrock. Despite these extreme climatic conditions, biological communities exist in the lakes, streams, and soils. These communities must be adapted to unusual physical conditions driven by both climate and latitude, which include extreme desiccation, freeze-thaw cycles, high winds, and unique light-dark cycles. Such environmental constraints are beyond the tolerance of many groups of organisms (Friedmann 1982, Freckman and Virginia 1997).

The McMurdo Dry Valleys are extremely climate-sensitive environments. Small variations in physical environment and climatic conditions within the dry valleys have profound effects on life in these ecosystems. Although Antarctica as a whole is undoubtedly highly climate sensitive (Smith et al. 1999), the McMurdo Dry Valleys are like-
THE COMBINATION OF WEAK SPATIAL

LINKAGES AND A NUTRIENT-DEFICIENT

ENVIRONMENT IN THE DRY VALLEYS MAKE

THE LEGACY OF PAST CLIMATIC

CONDITIONS HIGHLY RELEVANT TO

\section{CURRENT DRY VALLEY ECOSYSTEMS}

ly to be particularly sensitive because small climatic changes can lead to extreme variations in hydrologic regime (Dana et al. 1998, Fountain et al. 1998). This magnification has been referred to as polar amplification. It is now clear that what would, in more temperate regions, be considered very small variations in temperature and, to some degree, humidity and precipitation have potentially great impact in the McMurdo Dry Valleys.

The presence of liquid water remains the primary limiting condition for life in Antarctica (Kennedy 1993). Therefore, processes that affect the formation, location, and distribution of liquid water greatly influence ecological function and biological diversity in the McMurdo Dry Valleys. Understanding the role of present and past climate variability on the distribution of liquid water has been a major emphasis of the McMurdo LTER. In this article, we describe the physical environment of the McMurdo Dry

Andrew G. Fountain (e-mail: andrew@pdx.edu) is a professor in the Departments of Geology and Geography, Portland State University, Portland, OR 97207-0751. W. Berry Lyons is a professor of geochemistry and Loper Chair of Environmental Geology in the Department of Geology, University of Alabama, Tuscaloosa, AL 35487-0338. Melody B. Burkins is an adjunct assistant professor in the Department of Earth Sciences and Environmental Studies Program, and Ross A. Virginia is a professor and chair of Environmental Studies, Dartmouth College, Hanover, NH 03755. Gayle L. Dana is an assistant research professor and Robert A. Wharton Jr. is a research professor at the Water Resources Center, Desert Research Institute, Reno, NV 89512-1095. Peter T. Doran is an assistant professor in the Department of Earth and Environmental Sciences, University of Illinois, Chicago, IL 60607-7059. Karen J. Lewis is a graduate student at the Institute for Arctic and Alpine Research, and Diane M. McKnight is an associate professor in the Department of Civil, Environmental, and Architectural Engineering, University of Colorado, Boulder, CO 80309-0450. Daryl L. Moorhead is an associate professor in the Department of Biological Sciences, University of Toledo, Toledo, OH 436063390. Andrew N. Parsons is a research associate at the Natural Resource Ecology Laboratory, and Diana $\mathrm{H}$. Wall is director of the Natural Resource Ecology Laboratory and a professor in the Department of Rangeland Ecosystem Science, Colorado State University, Fort Collins, CO 80523-1499. John C. Priscu is a professor of ecology in the Department of Biological Sciences, Montana State University, Bozeman, MT 59717. (c) 1999 American Institute of Biological Sciences. 


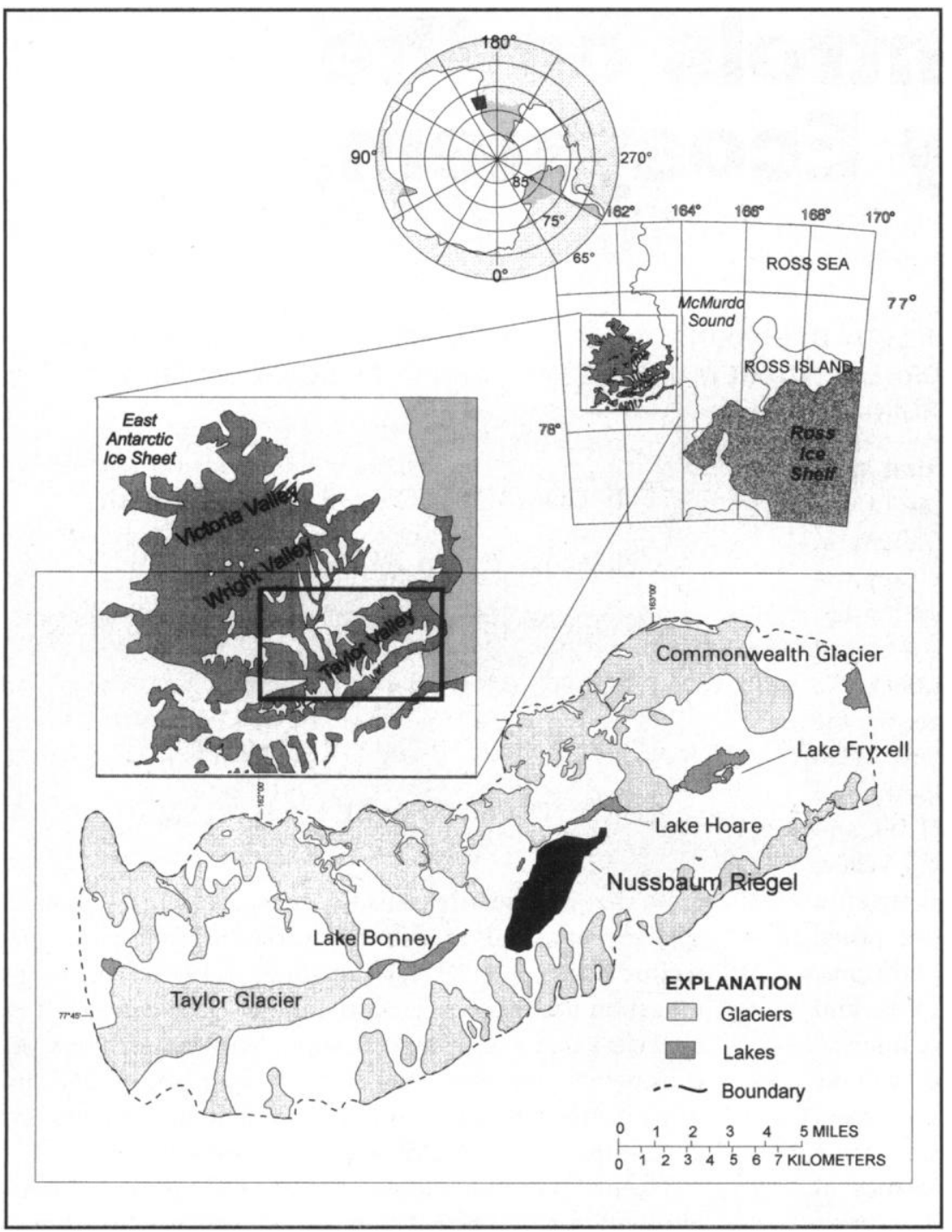

Figure 1. The Victoria, Wright, and Taylor Valley components of the McMurdo Dry Valleys. The other dry valleys (Garwood and Miers Valleys) are located $30 \mathrm{~km}$ to the south and are not shown here.

floors with large expanses of exposed bedrock (Figure 2). Much current debate exists over the pre-Quaternary climatic history of this region of Antarctica (e.g., Miller and Mabin 1998).

A recently developed geomorphological model divides the dry valleys into coastal, intermediate, and interior regions (Marchant and Denton 1996), which correspond roughly to regions that have been at low, intermediate, and high elevation since the mid-Pliocene (Wilch et al. 1993). The lowelevation coastal areas show modern soil movement; mid-elevation intermediate areas show evidence of soil activity only on moist, north-facing slopes; and soils of the high-elevation interior regions have changed little over the last 4 million or so years. The coastal zone corresponds to lowland soils containing lacustrine organic matter and marine signatures in glacial tills in both the upper and lower reaches of the valley (Burkins et al. in press). Interior regions are upland areas in high mountains (e.g., the Kukri Hills and Asgard Range) adjacent to Taylor Valley (Figure 1). The intermediate region corresponds to the higher elevations of Taylor Valley that lie between the moun-

Valleys and outline the current understanding of the climatic controls in the dry valleys. The data we present will also provide background for the more biologically focused manuscripts on the McMurdo Dry Valleys in this issue of BioScience.

\section{Setting}

The McMurdo Dry Valleys exist because the Transantarctic Mountains block much of the flow of the East Antarctic Ice Sheet toward McMurdo Sound (Chinn 1990). In addition, at the level of the valley floor, ablation (mass loss in all its forms) of snow and ice exceeds accumulation during all seasons. Glaciers descend from the surrounding mountains; the largest glaciers reach the valley floor and terminate in cliffs $20 \mathrm{~m}$ high. During the warm periods of the austral summer, ephemeral streams flow from the glaciers toward the lakes. Taylor Valley is approximately 35 $\mathrm{km}$ long and contains three major lakes (Lakes Bonney, Hoare, and Fryxell) and more than 24 ephemeral streams (Figure 1). The physical appearance of Taylor Valley and the dry valleys is characterized by sandy gravel valley tains and the lowland areas.

These lower, middle, and upper elevations have experienced different microenvironmental regimes, which have differentially affected local biological communities, as indicated by the sizes and isotopic signatures of organic matter and nutrient concentrations (Burkins et al. in press). Understanding the historic context of landscapes is crucial to understanding all ecosystems (Swanson et al. 1988), but such an understanding is particularly important in the case of the McMurdo Dry Valleys, where past climatic variations dictate current ecosystem status. Because of its polar location and the paucity of biota, the primary disturbances in the McMurdo Dry Valley ecosystem have been climatic, and landscape pattern has been primarily controlled by climatic, and not biotic, processes.

The McMurdo Dry Valleys region is considered a cold desert. The very low amount of precipitation falls mainly as snow, although small amounts of rain have been known to occur during the summer (Keys 1980). At Lake Vanda in Wright Valley, average annual snowfall over 3 years was 6 $\mathrm{cm}$ water equivalent, with an annual maximum of $10 \mathrm{~cm}$ 
and a minimum of $0.6 \mathrm{~cm}$ (Bromley 1985). Easterly winds bring precipitation as low-pressure systems pass over open water in the Ross Sea. These systems then drop moisture in the dry valleys as the air begins to rise over the Transantarctic Mountains (Bromley 1985). Precipitation decreases westward in the valleys, as the distance from the ocean increases (Keys 1980, Fountain et al. in press). Winds are typically high in the dry valleys, with monthly average wind speeds in Taylor Valley ranging from $2 \mathrm{~m} / \mathrm{s}$ to $4 \mathrm{~m} / \mathrm{s}$ (Clow et al. 1988). Wind-carved ventifacts are common in the valleys and testify to the windy environment.

Glaciers in Taylor Valley are generally polar alpine, being characterized by ice temperatures that are well below freezing, with the base of the glaciers frozen to the rock substrate. The alpine glaciers flow from the Asgard Range on the north side of the valley and from the Kukri Hills on the south side (Figure 1). However, Taylor Glacier, the largest glacier in the valley, flows into the valley from the west (Figure 1) and is not an alpine glacier but rather an outlet glacier of the East Antarctic Ice Sheet. The glaciers flowing from the Asgard Range are, on the average, three times the area of those flowing from the Kukri Hills. This difference results from topographic differences-the Asgard Range forms higher and larger snow accumulation basins. Also, the glaciers in the Kukri Hills are smaller because they are exposed to more solar radiation resulting from their north-facing aspect and from the higher solar angle when the sun is in the north.

In contrast to glaciers in temperate alpine regions, the mass gains and losses of the glaciers in Taylor Valley are relatively small. Our observations of the glaciers (Fountain et al. 1998) indicate that approximately $10-30 \mathrm{~cm}$ of snow accumulates in the upper zones and approximately 6-15 $\mathrm{cm}$ is lost from the ablation zone, amounts that are consistent with results from studies in the adjacent Wright Valley (Bull and Carnein 1970, Chinn 1980). The important components of ablation in Taylor Valley are evaporation, sublimation, and melting. Preliminary results from Canada Glacier collected from 1993 to 1998 indicate that during the summer, evaporation and sublimation account for $70 \%$ of the mass loss from the glacier surface; the remaining $30 \%$ is lost by melt (Lewis et al. 1998). The snow in the upper reaches of the glaciers is cold and dry, and no snowmelt has been observed directly, although the presence of thin ice lenses in the snowpack does indicate previous snowmelt events. It is most likely that the snowmelt is refrozen in the snow and that no runoff from the accumulation zone occurs. Meltwater generated in the ablation zone, including the $20 \mathrm{~m}$ high ice cliffs that often form the termini of many of the glaciers, is the primary souce of water in Taylor Valley.

Ephemeral streams transport the glacial meltwater to terminal lakes that lose water only through sublimation and evaporation. Like terminal lakes elsewhere (e.g., Great Salt Lake), dry valley lakes are sensitive to small changes in water inflow. The only source of water to the streams is glacial melt during the austral summer (Conovitz et al. 1998). These ephemeral streams are channeled, and, given the absence of rain and overland flow, the soils between streams are dry, gaining moisture only from occasional snowmelt and sublimating permafrost below (McKay et al. 1998). Snowfall in the dry valleys does not contribute significantly to the streams or to the general hydrology of the valleys because it usually sublimates before melting (Chinn 1981). However, the accumulated snow piled against the glacier termini by winds that sweep the valley floor or by snow drifting off the glaciers (Fountain et al. 1998) does contribute to the early spring melt before disappearing early in the summer season.

Continuous permafrost occurs at shallow depths a few tens of centimeters beneath the soil surface (Campbell et al. 1998). Therefore, groundwater flow in the dry valleys is probably limited to the near-surface hyporheic zone (the saturated zone adjacent to and under the stream channel) along the margins of stream channels (McKnight et al. 1999). However, seepage meters in the bottom of Lake Hoare indicate a very small flux of groundwater, pointing to the possibility of deep groundwater movement in Taylor Valley (Scott Tyler, Desert Research Institute, Reno, NV, unpublished data). Substantial groundwater flow has, however, been observed in Wright Valley (Cartwright and Harris 1981).

The ephemeral streams of Taylor Valley lack allochthonous organic input, but they can support relatively high standing algal biomass with low primary productivity because grazing losses are low (McKnight and Tate 1997, Webster and Meyer 1997). The streams are important to the lakes as sources of nutrients and organic carbon and as conduits of water to replace the lake water lost by evaporation and sublimation. Glacier meltwaters are a source of nutrients, especially for the spring flush of particulate matter accumulated on the ice during winter and during low flows late in the season (Howard-Williams et al. 1998). Solutes are also generated by weathering of streambed materials (Lyons et al. 1998a) and from water draining the hyporheic zone.

Lakes up to $80 \mathrm{~m}$ deep occupy the lowest portions of each of the McMurdo Dry Valleys and are covered with perennial ice that is $3-6 \mathrm{~m}$ thick. A moat of water forms at the edge of the lakes during most summers as the ice near the shore melts completely. Because the lakes are permanently hydrated and the ice cover provides a buffer from seasonal temperature fluctuations and protection from mechanical mixing by wind, they are the only dry valley habitat that supports microbial activity year-round. The lakes have abundant planktonic and benthic microbial populations (Seaburg et al. 1983, Wharton et al. 1983, Vincent 1988, Lizotte and Priscu 1998), and their food webs consist of viruses, bacteria, algae, heterotrophic protozoans, and rotifers (Kepner et al. 1997, 1998, 1999, Laybourn-Parry et al. 1997, James et al. 1998, Priscu et al. 1999). The ice covers of these lakes also harbor a commu- 


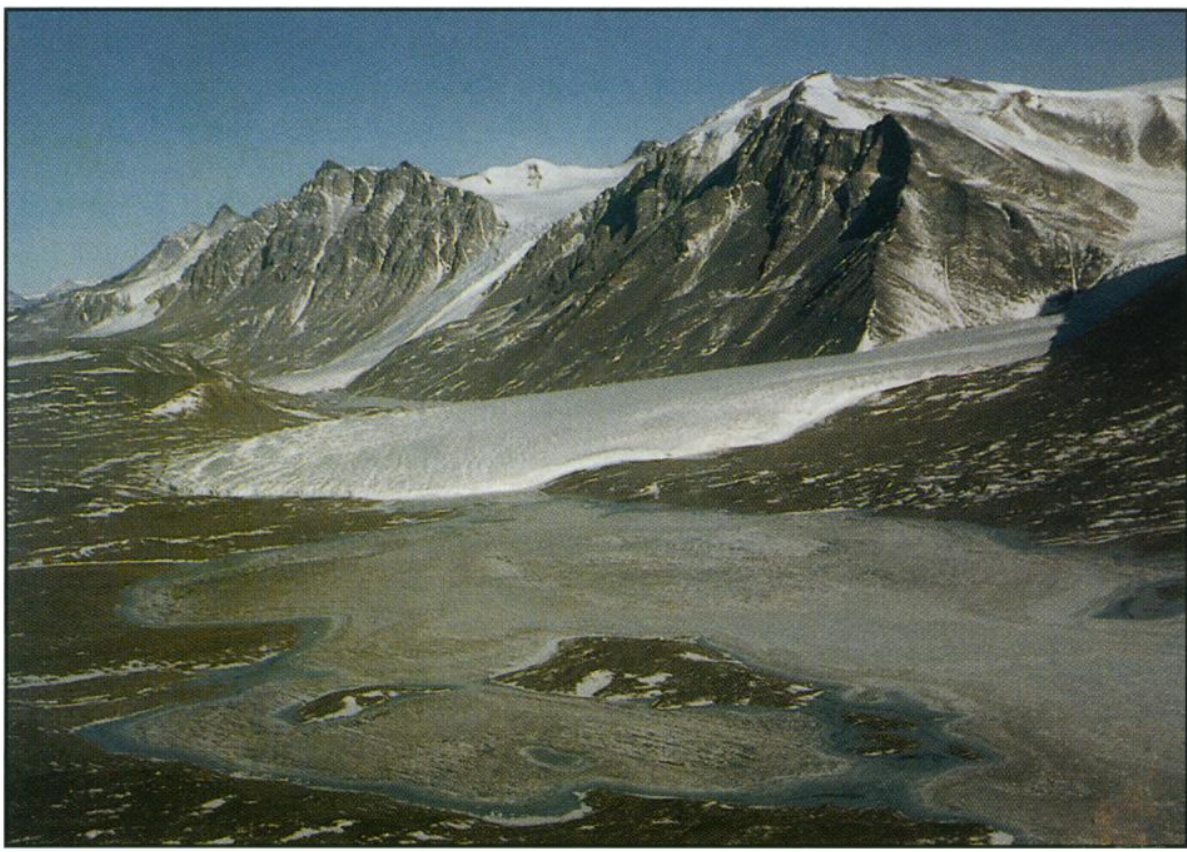

Figure 2. Physical appearance of Taylor Valley. Lake Fryxell is in the foreground and Canada Glacier is in the background. The view is toward the west.

nity of prokaryotic phototrophs and heterotrophs that produce new carbon (Adams et al. 1998, Fritsen et al. 1998, Priscu et al. 1998). Particulate organic matter synthesized within the ice cover and released through passages in the ice to the lake bottom may provide the biological inoculum for some of the benthic organisms that inhabit the lake.

The glaciers in the dry valleys also provide habitat for microbial activity (Wharton et al. 1985, John C. Priscu, unpublished data). Melt pools that form on the lower portion of many glaciers become traps for aeolian-transported material. This darker material absorbs more solar radiation than the surrounding ice and melts into the glacier, forming cylindrical water-filled depressions called cryoconite holes.

The main factors controlling the level of biodiversity in the dry valleys are the availability of water and of physical energy (solar radiation and temperature). Because the dry valleys are typically near the minimum level of adequate energy and water to sustain living organisms, spatial and temporal variations in these factors control the large-scale patterns of life in the dry valleys (Moorhead and Priscu 1998). These patterns are modified by the biogeochemical gradients of the soils and lakes, which are related to climate and geological setting. Energy and water availability are more strongly interrelated in the dry valleys than in temperate systems because all of the water available to the ecosystem exists in the frozen reservoirs of the glaciers that surround the valley. Energy is required to melt the ice and create water. In the McMurdo Dry Valleys, the freezing/ melting temperature of ice $\left(0^{\circ} \mathrm{C}\right)$ is a binary switch. When air temperature is below $0{ }^{\circ} \mathrm{C}$, little or no surface water is present and the lakes represent the only viable habitat in the valleys, but one whose long-term existence is dependent on an influx of water. Above $0{ }^{\circ} \mathrm{C}$, meltwater is produced and fluvial and lacustrine habitats flourish. Presently, this period of glacier melt, which produces liquid water, usually occurs during a 6-10 week period within the austral summer from November through January.

\section{Spatial changes: landscape.}

Spatial variations in topography created local depressions that filled with water to form the lakes observed today. The Taylor Valley lakes (Figure 1) were formed, in part, by the advance of the West Antarctic Ice Sheet into Taylor Valley approximately 40,000 years ago (Denton et al. 1989). Lake Washburn was produced as the ice sheet melted. The resulting liquid water was blocked by the West Antarctic Ice Sheet and did not flow into McMurdo Sound (Figure 1). The three lakes observed in the valley today are remnants of this large glacial lake (Doran et al. 1994, Lyons et al. 1999). The debris deposited by the ice sheet forms a wide, low ridge along the marine outlet of Taylor Valley and created the enclosed basin that is now occupied by Lake Fryxell. The division between the Lake Bonney basin at the western end of Taylor Valley and the Lake Fryxell basin at the eastern end is the Nussbaum Riegel, a $700 \mathrm{~m}$ bedrock ridge that bisects Taylor Valley. The Lake Hoare basin is the smallest of the three main basins and is essentially an ice-dammed lake. If Canada Glacier, which forms part of the boundary of Lake Hoare, were to retract, Lake Hoare would flow east, into Lake Fryxell.

The streams of the McMurdo Dry Valleys flow through an unconsolidated alluvium and are remarkably similar throughout the valleys. This uniformity of substrate results in many recurring features of the streambeds and the stream banks. Which features are expressed in each stream seems to be controlled by the topography and by hydrologic and periglacial processes. Perched deltas also exert an important geomorphic influence on the landscape. These deltas are relicts of previous climatic conditions, when streams deposited their sediment loads into lakes with much higher water levels. In particular, the configuration of the larger rocks in the stream channels is controlled mostly by fluvial and periglacial processes, in contrast to the large rocks on the landscape away from the stream channels, whose configuration is controlled by the strong winds.

In general, the common characteristics of the streams, 
moving downstream from the stream source at a glacier to a lake, include:

- At the base and sides of the source glaciers, the streams flow along the moraine and through or around the calved ice. These streams are often frozen over with a thin ice cover.

- In areas of ice-bound moraine, there is no alluvium, and the stream flows over and around the frozen rocks.

- In steep gradient reaches, the active channel is approximately

5-20 m across, with steep stream banks at the angle of repose of the alluvium. Large jumbled rocks are present in the streambed, with deposited sediment abundant at the margins of the active channel.

- In moderate-gradient reaches, the active channel is com posed of rocks that are wedged together in a flat stone pavement, with steep stream banks at the angle of repose of the alluvium and less sediment deposition than in steep gradient reaches.

- In both steep and moderate gradient reaches, the streams can cut through a perched delta containing organic-rich sediment.

- In shallow-gradient reaches near the lakes or secondorder streams in valley bottoms, which receive sediment from tributaries, a sandy braided channel exists, with low banks at the angle of repose of the alluvium.

These characteristic morphologies control the watervelocity distribution in the cross-section and the substrate for growth of algal mats, presenting distinct habitats for algal communities in the streams. Studies of stream algal communities show that different groups of algal species occur in different habitats. Algal abundance is greatest in reaches with stone pavements and abundant perennial cyanobacterial mats and lowest in streams flowing through ice-bound moraine and along the base of glaciers (McKnight et al. 1998). The spatial distribution of these habitats thus determines the spatial distribution of algal biomass in the streams.

Many old deposits of alluvium or residual talus slopes in arid regions develop armors of closely packed material or stone pavements (Breed et al. 1989); a similar phenomenon occurs in the dry valleys of Antarctica (Campbell and Claridge 1987). The stone pavements in shallow-gradient streams in the McMurdo Dry Valleys probably form through the long-term action of the freezing of the saturated alluvium at the end of the summer and the thawing of the alluvium at the beginning of the summer; as a result of this action, the larger rocks are rotated until the larger sides are upward and these rocks then become wedged together across the streambed. The high porosity of the alluvium could be a factor in the freeze-thaw action. On steeper slopes, the hyporheic zone may drain before sufficient freeze-thaw action can line the streambed with larger rocks wedged together. In addition, the high flow velocities during seasonal large-flow events in these highergradient channels may erode the sand between the rocks near the central flow region of the stream, further destabilizing the rocks.

Thus, topographic differences in Taylor Valley control the distribution of different stream habitats and, in turn, the abundance of algal communities in the streams. In the Lake Fryxell basin, the valley sides on the south side of the basin are more gently sloped than those on the north side, and there are long reaches in which stone pavements and thick perennial mats of filamentous cyanobacteria occur (McKnight et al. 1998). In the Lake Bonney basin, the sides of the valley are much steeper, and steep-gradient streams are common. Consequently, stone pavements are not found, and algal growth is restricted mainly to colonial green algae growing on the underside of rocks. Sediment movement undoubtedly limits algal mat abundance in the shallow-gradient reaches of stream outlets to the lakes. The presence or absence of stream algal mats has important consequences for the planktonic lake communities because these algal communities absorb nutrients such as nitrate and phosphate (McKnight et al. 1998, Moorhead and Priscu 1998), thereby decreasing the flux of these nutrients to the lakes. These communities may, however, also fix nitrogen and release carbon and nitrogen to the lakes via stream export (Downes et al. 1986).

The stream channels can also act as traps for blowing snow and sediment during the year. Sediment deposited in a channel may cover the algal mats until the flow is sufficient to transport the aeolian sediment down to the lower reaches of the stream or into the lakes. Most of the aeolian sediment probably accumulates during winter, when the winds are the highest and water flow is absent. This sediment is then flushed during the summer meltwater flow. Only recently have we begun to better quantify particulate 


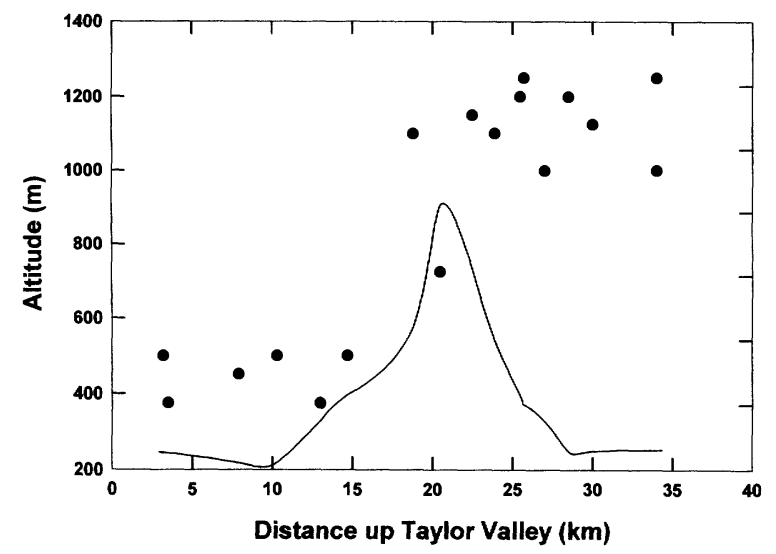

matter fluxes from the streams into the lakes (W. Berry Lyons, Kathy Welch, Carmen Nezat, unpublished data).

Spatial changes: climate. The longitudinal and vertical gradients in climate of the dry valleys dictate the gradient of species diversity. The topography of the dry valleys ranges from an average valley floor altitude of approximately $30 \mathrm{~m}$ to approximately $2000 \mathrm{~m}$ on the mountain peaks in a horizontal distance of only a few kilometers. Taylor Valley sustains an especially large climatic gradient. Meteorological data show that the western end of the valley at Lake Bonney is warmer, drier (even when corrected for the temperature difference), and windier than the eastern end, at Lake Fryxell (Table 1). Although the causes of the climate differences have not been fully elucidated, we hypothesize that there are two interrelated controls. One control is an interaction between the dry katabatic winds that flow off the interior ice sheet and the coastal breezes from the sea ice (Bromley 1985). The katabatic winds warm adiabatically as they descend from the ice sheet, whereas the coastal breezes tend to be cool as they advect into the valley from the ice-covered McMurdo Sound. The interplay and spatial influence of these two wind systems usually result in an up-valley, Lake Fryxell-to-Lake Bonney increase in air temperature and wind speed.

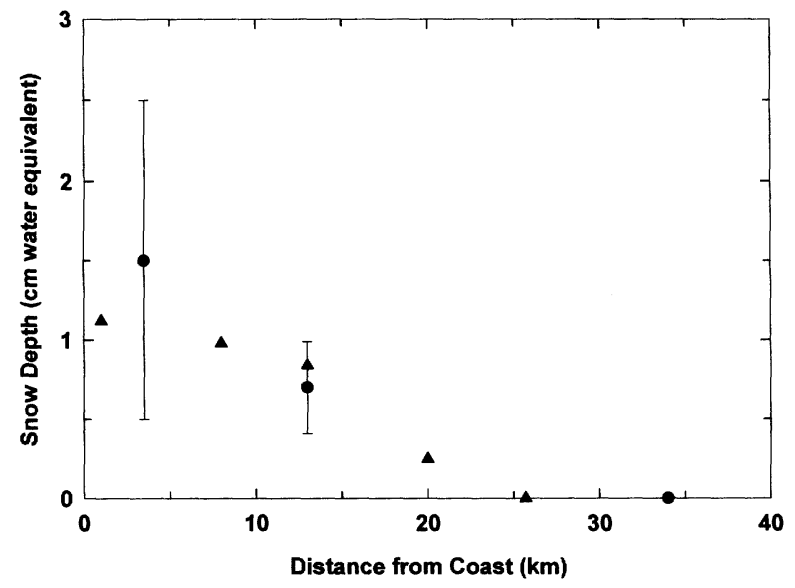

Figure 3. Snow depth in Taylor Valley with distance away from the coast. Solid circles show snow accumulation from November 1996 to January 1997, between $200 \mathrm{~m}$ and $300 \mathrm{~m}$ elevation on three glaciers. Solid triangles represent snow depth on the valley floor just after a snowfall in January 1997. The bars represent the range of snow depths within the elevation range on the glaciers. The Lake Fryxell basin extends from approximately $2 \mathrm{~km}$ to $15 \mathrm{~km}$, and the Lake Bonney basin extends from $22 \mathrm{~km}$ to $36 \mathrm{~km}$.

The second control is provided by the Nussbaum Riegel, which diagonally bisects the valley at approximately $20 \mathrm{~km}$ inland. The Nussbaum Riegel enhances the climatic difference between the two parts of the valley by largely confining the effects of the katabatic and coastal winds to the western and eastern parts of the valley, respectively. It also retards precipitation-bearing coastal storms from reaching the Lake Bonney basin. This effect is evident in differences in snow depths (Figure 3) at constant elevation on the glaciers, and it was dramatically illustrated by a snowstorm on 12 January 1997: Lake Fryxell basin was covered in snow, decreasing in depth from the coast, whereas snow was absent from the floor of Lake Bonney basin.

The significance of this spatial pattern of temperature and precipitation can be observed in the position of the glacier equilibrium line altitude (ELA; Figure 4), which divides the zone of yearly net mass accumulation (typically snow) from the zone of net mass loss by melt and sublimation. Figure 4 also shows that the rapid rise in the ELA is associated with the position of the Nussbaum Riegel. Modeling of the ELA rise based on the difference in climatic variables across the Nussbaum Riegel supports this conclusion (Fountain et al. in press).

The hydrologic response to this longitudinal climatic gradient in Taylor Valley is profound. The combined factors of warmer air temperatures, less humidity, and greater wind speed greatly increase ice sublimation in the western part of the valley and, hence, glacier ablation (Lewis et al. 1998). The effect of these climatic variables on stream flow is unclear, because although warmer temperatures should create more meltwater, this increase appears to be compensated for by greater evaporation from higher wind speeds. Moreover, because most of the glaciers in the Lake Bonney basin are at higher elevations than those in the eastern end of the valley, resulting from the increase in

Figure 4. The change in glacier equilibrium line altitude (ELA) and mid-valley altitude with distance up Taylor Valley. The origin of the distance scale is McMurdo Sound. The line is the altitude of the mid-valley profile, and the solid circles represent the glacier ELAs. The Nussbaum Riegel is the peak of the valley profile at approximately $20 \mathrm{~km}$. The Lake Fryxell basin extends from approximately $2 \mathrm{~km}$ to $15 \mathrm{~km}$, and the Lake Bonney basin extends from $22 \mathrm{~km}$ to $36 \mathrm{~km}$. 
ELA, these glaciers should produce less meltwater. Interestingly, increasing precipitation also acts to decrease runoff by changing the heat balance and albedo (ratio of outgoing to incoming solar radiation) of the glacier ice, as can be demonstrated by our recent findings on glacier dynamics (Fountain et al. 1998).

The mean summer air temperature for the past 5 years in Taylor Valley has been below the freezing point of fresh water (Table 1), which has minimized glacier melt. However, the absorption of solar radiation by the ice warms it to the melting point, and as a result the timing of peak values of daily stream discharge is determined by glacier orientation relative to the position of the sun as it circles above the horizon (Conovitz et al. 1998, Dana et al. 1998, Lewis et al. in press). In fact, during early and late summer, and during particularly cool periods in midsummer, marginal ice cliffs are the primary water source because they receive more intense solar radiation than the surface of the glacier (Fountain et al. 1998, Lewis et al. in press) - that is, because the angle between the sun and near-vertical cliffs is closer to perpendicular than that between the sun and the sub-horizontal surface of the glacier.

Precipitation (snow) changes the heat balance by increasing the albedo of the glacier surface from that of ice (approximately 0.4 ) to that of fresh snow (as high as 0.9 ). Even thin layers of snow, just a few centimeters thick, can persist for weeks, largely terminating runoff except from the ice cliffs, which do not accumulate snow. A $20 \%$ increase in albedo occurred on the ice-covered parts of glaciers in the Lake Fryxell basin from January 1994 to January 1995 due to more extensive snow cover (Dana et al. 1998). This increase in albedo effectively eliminated solar radiation as a source of heat, and much of the glacier surface remained below freezing and reduced stream flow in the 1994-1995 austral summer. The difference in snow cover between the Lake Fryxell and Lake Bonney basins is shown in Figure 3.

Increased snowfall in the Lake Fryxell basin compared to the Lake Bonney basin (Figure 3) results in a different interannual pattern of runoff in the two basins. In the Lake Fryxell basin, yearly runoff is variable between glaciers because the spatial patterns of snowfall vary (Figure $5 a)$. In comparison, yearly runoff in the Lake Bonney basin is consistent among glaciers because of the general lack of snow (Figure 5b). This difference between basins may explain why Lake Bonney has been rising faster than either Lake Fryxell (Figure 6) or Lake Hoare over the past 20 years (Chinn 1993). The steeper shoreline of Lake Bonney than Lake Fryxell may also enhance the difference in rise between the lakes.

Snow also has a direct effect on lake communities, by significantly reducing the penetration of sunlight through the permanent ice covers and into the underlying water column (Priscu 1991, Adams et al. 1998, Fritsen et al. 1998, Howard-Williams et al. 1998, Fritsen and Priscu 1999). The phytoplankton in the water column of the lakes has
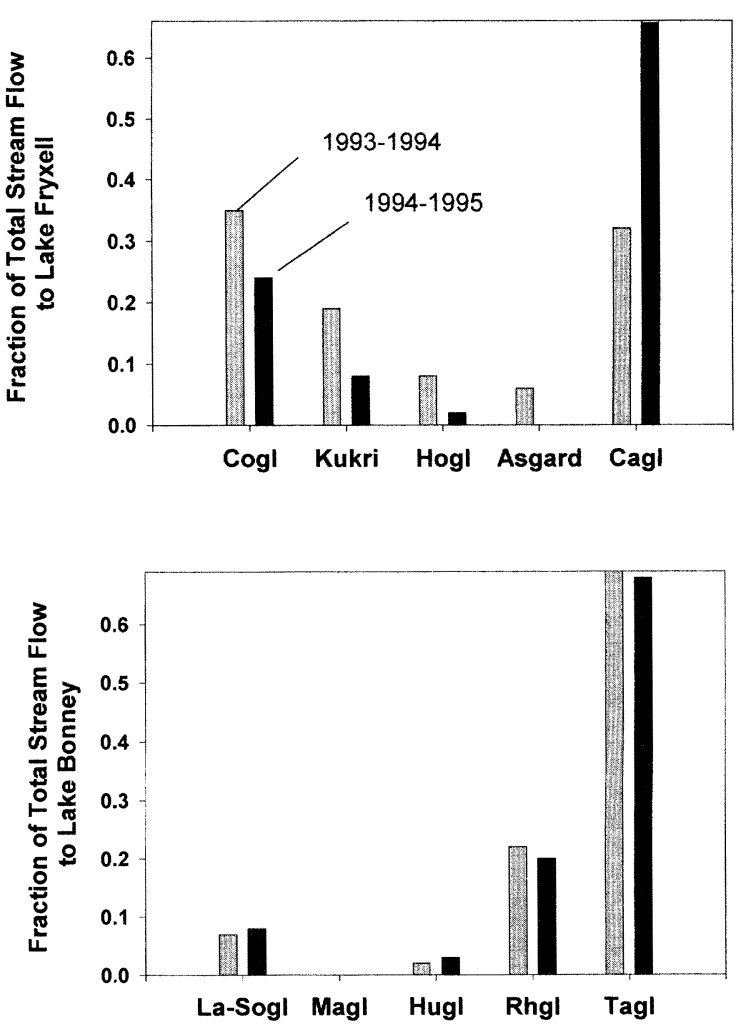

Figure 5. Variations in runoff from several different glaciers from two lake basins in two different summer seasons, 1993-1994 and 1995-1995, expressed in terms of fraction of total runoff. (a) Stream flow to Lake Fryxell from the Commonwealth (Cogl), Kukri Hills (Kukri), Howard (Hogl), Asgard Range (Asgard), and Canada (Cagl) glaciers. (b) Stream flow to Lake Bonney from the LaCroix and Suess (La-Sogl), Matterhorn (Magl), Hughes (Hugl), Rhone (Rhgl), and Taylor (Tagl) glaciers. Gray bars, 1993-1994; black bars, 1995-1996. The 1993-1994 summer season was characterized by a lack of snow in both basins, whereas in the 1994-1995 season, the overall air temperatures were cooler and snowfall occurred in the Lake Fryxell basin.

been shown to be light limited (Lizotte and Priscu 1992), so any change in the underwater light field will influence rates of primary productivity. Perhaps of more importance to the microbial communities within the ice (Priscu et al. 1998, 1999) and in the underlying lake water (Morgan et al. 1998, Neale and Priscu 1998) is the fact that snow also reduces the intensity of the photosynthetically active radiation to levels that are more typical of spring and late summer, when natural light levels are low. In the same way that snow reflects solar radiation from glaciers, it also reflects radiation energy from the lakes (Dana et al. 1998) and may reduce ice temperature.

The level of snowfall also affects the composition of terrestrial communities. The Lake Fryxell basin provides a more favorable habitat for soil organisms than the Lake 


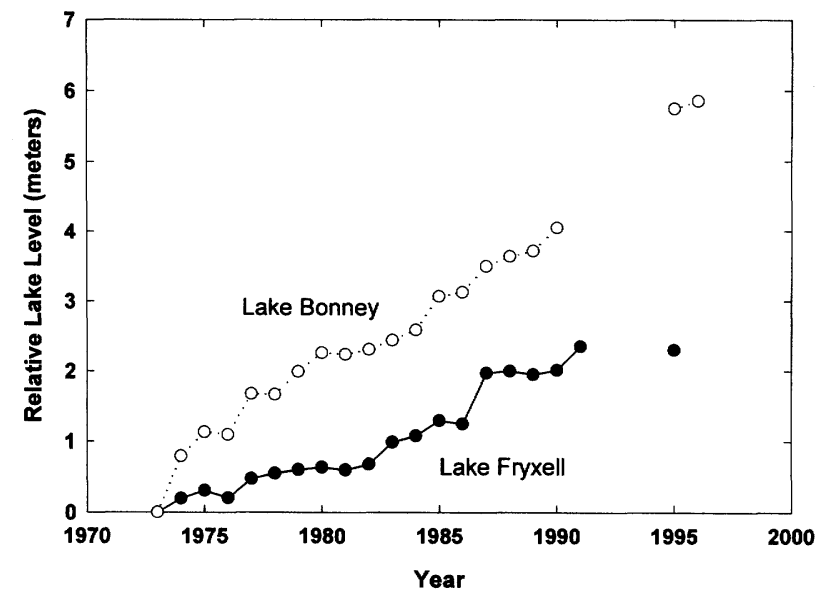

Bonney basin because the greater snowfall elevates soil moisture. Moreover, the warmer temperatures, lower humidity, and higher wind speeds of the Lake Bonney basin desiccate the soils to a greater degree than in the Lake Fryxell basin.

The climatic gradient in Taylor Valley also produces a gradient in salt distribution. In general, the soluble ion and dust content of the Taylor Valley glaciers decreases with elevation and distance from the ocean. A similar trend has already been recognized for Antarctica as a whole (Welch 1993, Mulvaney and Wolff 1994), and in this case it has been largely explained by relative proximity to a marine source. However, not all salts come directly from marine sources. For example, some ion concentrations in snow from the Ross Ice Shelf (sitting directly on the ocean) are lower than those of the Commonwealth, Howard, and Canada glaciers in Taylor Valley. This extra salt must originate from the valley floor (Mayewski et al. 1995). Interestingly, the overall chemistries of these glaciers are very different (W. Berry Lyons, Kathy Welch, Carmen Nezat, unpublished data), perhaps because marine aerosols, in addition to wind-blown salts and dust from the valley floor, are differentially added to these glaciers.

Temporal changes: seasonal and annual. For approximately 2-3 months in the austral summer, the dry valley climate is characterized by continuous daylight, near-freezing air temperatures, and the presence of meltwater flow. During the 7 months of winter, darkness is nearly continuous, surface water is absent, and air temperatures on the valley floor plummet to as low as $-40{ }^{\circ} \mathrm{C}$ (Clow et al. 1988). In response, dry valley organisms have developed a number of survival strategies. For example, when stressed by the extreme cold and drought of the dry valleys, nematodes enter a state of anhydrobiosis or cryptobiosis (Powers et al. 1994) in which they can survive for decades (Freckman 1986).

One of the limiting factors to biological activity in the dry valley lakes is the seasonal light regime. Certain planktonic species have adapted to the long periods of dark by
Figure 6. A comparison of lake-level rise of Lake Fryxell and Lake Bonney (Chinn 1993). Black circles, Lake Fryxell; open circles, Lake Bonney.

using a mixotrophic strategy, whereby they photosynthesize during illuminated periods and graze on bacteria during dark periods (McKnight et al. 1998, Priscu et al. 1999, Roberts and Laybourn-Parry 1999). This strategy enhances survival of lake communities during the dark winter and during those occasional periods in summer when snow accumulation reduces solar radiation, thus limiting photosynthesis, and decreases stream-supplied nutrients. The spring flush of nutrient-rich waters is partly responsible for the spring algal growth in the lakes (Lizotte and Priscu 1998), which have been shown to be highly phosphorus limited (Priscu 1995).

Long-term changes (centuries to millennia) and the importance of past climates. Like most glaciated regions in temperate zones, the dry valleys have been subject to vast climate changes that have caused glaciers to advance and retreat. The East Antarctic Ice Sheet and the West Antarctic Ice Sheet, as represented by the Ross Ice Shelf, have advanced and retreated many kilometers over the past tens of thousands of years (Hendy et al. 1979, Denton et al. 1989). Surprisingly, however, the alpine glaciers of the dry valleys seem to have maintained their position within a few hundred meters for the past 3.5 million years (Hall et al. 1993, Wilch et al. 1993).

Since the last glacial maximum, the lakes in Taylor Valley have undergone large variations in size (Doran et al. 1994, Lyons et al. 1998b). Glacial Lake Washburn inundated the valley starting approximately 40,000 years ago to depths of more than $300 \mathrm{~m}$ above current lake levels (Denton et al. 1989). By approximately 7000 years ago, the West Antarctic Ice Sheet receded, and Lake Washburn drained. Next followed a warm period, during which lakes in the McMurdo Dry Valleys increased in size, reaching a maximum depth approximately 3000 years ago. Colder and drier conditions then prevailed until $1500-1000$ years ago, when the lake levels declined considerably, with some desiccating completely (Lyons et al. 1997, 1998b, 1999). During the last 1000 years, the climate has become warmer and lake levels have risen. As the lakes have waxed and waned, lacustrine organic matter has been deposited and become incorporated into the soil.

We are finding that these past conditions significantly influence the structure and function of the ecosystem today. For example, Priscu (1995) observed that new phytoplankton production in Lake Bonney is supported by the upward diffusion of nutrients from deep nutrient pools. These pools differ quantitatively between lakes, as does the overall geochemistry. The geochemical differences may be related to the differing evolution of the lakes, because current biochemical reactions and physical 
processes do not appear to be responsible for the lakes' current chemical composition (Priscu 1995, 1997, Lyons et al. 1997). Examination of the geochemical profiles of the lakes suggest that the differences between lakes are related primarily to their drawdown roughly 1200 years ago, which concentrated ions and associated salts (Lyons et al. 1997, 1998b, 1999). Indeed, the deep waters of Lake Bonney in Taylor Valley (Matsubaya et al. 1979) and Lake Vanda in Wright Valley (Wilson 1964) are remnants of smaller, hypersaline lakes.

The long-held assumption has been that the organic matter in dry valley soils was derived from aeolian-transported material from modern aquatic environments. However, recent analyses of isotopic signatures of the organic material and spatial correlation with the glacial tills in Taylor Valley suggest that the primary source is ancient marine and lacustrine sediments (Burkins et al. 1998). The marine sediments are thought to be derived from seawater trapped in the valley during the Pliocene (McKelvey 1982) and from the scouring of marine sediments by the incursion of the Ross Ice Shelf into the valley 22,000-5000 years ago (Stuiver et al. 1981). Lacustrine sediments result from the presence of Lake Washburn and other lakes since the Pliocene. Thus, much of the soil of Taylor Valley is a net donor of organic material to the lakes rather than a sink, as had previously been thought.

\section{Influence of past climate and ecosystem linkages}

The McMurdo Dry Valley ecosystems are shaped by lack of moisture, extreme cold, and low light. Water is transported by melting of the glaciers, whereas nutrients and other salts are transported by atmospheric input. The only direct links between the terrestrial, fluvial, and lacustrine ecosystems are the hyporheic zone along the margin of stream channels and the wetted soil along the lake shores. Therefore, the terrestrial and aquatic systems are linked in different ways than they are in other continental systems, where runoff and erosion lead to the transfer of terrestrial organic matter to aquatic ecosystems. Present-day climatic gradients in the McMurdo Dry Valleys, although subtle by temperate-region standards, greatly influence year-toyear ecosystem variability. Past climatic history continues to exert significant control on ecosystem structure and biodiversity (Moorhead et al. 1999).

The combination of weak spatial linkages and a nutrient-deficient environment make the legacy of past climatic conditions highly relevant to the current dry valley ecosystems. The importance of legacy in Taylor Valley suggests in turn that the habitats are linked across time. Because much of the water available to the ecosystem is locked in the frozen state, small changes in summer air temperature, which hovers around $0{ }^{\circ} \mathrm{C}$, determine the presence or absence of water. The current structure of the Taylor Valley ecosystem is thus a result of the interplay between landscape evolution, climatic gradients, and the legacy of past environments, which together control the distribution of energy, water, nutrients, and life.

\section{Acknowledgments}

Much of the focus of this paper evolved from discussions between the McMurdo LTER project members (i.e., the authors) and our two review panels. In particular we would like to thank Carl Bowser, University of Wisconsin; George Kling, University of Michigan; and Nancy Grimm, Arizona State University. Discussions with Gary Clow, Chris McKay, Brenda Hall, and Dave Marchant about the dry valley environment, past and present, have always been rewarding. Also, we owe much to those who immediately preceded us in the dry valleys, including George Simmons and William Green. We are particularly grateful to Rebecca Chasan and three anonymous reviewers of the original manuscript for their very helpful comments and suggestions. Finally, we have gained much from our international colleagues, including Ian Hawes, Clive HowardWilliams, Warwick Vincent, and Johanna Laybourn-Parry, who generously shared their time and expertise with us. This work was supported by the National Science Foundation's Office of Polar Programs, grant nos. OPP-9211773 and OPP-9813061, and expedited by the excellent services of Antarctic Support Associates.

\section{References cited}

Adams EE, Priscu JC, Fritsen CH, Smith SR, Brackman SL. 1998. Permanent ice covers of the McMurdo Dry Valley Lakes, Antarctica: Bubble formation and metamorphism. Pages 281-296 in Priscu JC, ed. Ecosystem Dynamics in a Polar Desert: The McMurdo Dry Valleys, Antarctica. Antarctic Research Series, Vol. 72. Washington (DC): American Geophysical Union.

Breed CS, McCauley JF, Whitney MI. 1989. Wind erosion forms in arid zone geomorphology. Pages $284-310$ in Thomas DSG, ed. New York: Halsted Press.

Bromley AM. 1985. Weather Observations: Wright Valley, Antarctica. Wellington (New Zealand): New Zealand Meteorological Service. Information Publication 11.

Bull C, Carnein CR. 1970. The mass balance of a cold glacier: Meserve Glacier, south Victoria Land, Antarctica. International Association of Hydrological Sciences 86: 429-446.

Burkins MB, Chamberlain CP, Virginia RA, Freckman DW. 1998. Natural abundance of carbon and nitrogen isotopes in potential sources of organic matter to soils of Taylor Valley, Antarctica. Antarctic Journal of the United States 31: 209-210.

Burkins MB, Virginia RA, Chamberlain CP, Wall DH. In press. The origin of soil organic matter in Taylor Valley, Antarctica. Ecology.

Campbell IB, Claridge GGC. 1987. Antarctica: Soils, Weathering Processes and Environment. Developments in Soil Science, Vol. 16. Amsterdam: Elsevier Science.

Campbell IB, Claridge GGC, Campbell DI, Balks MR. 1998. The soil environment of the McMurdo Dry Valleys, Antarctica. Pages 297-322 in Priscu JC, ed. Ecosystem Dynamics in a Polar Desert: The McMurdo Dry Valleys, Antarctica. Antarctic Research Series, Vol. 72. Washington (DC): American Geophysical Union.

Cartwright K, Harris HJH. 1981. Hydrogeology of the Dry Valley region, Antarctica. Pages 161-184 in McGinnis LD, ed. Dry Valley Drilling Project. Antarctica Research Series, Vol. 33. Washington (DC): American Geophysical Union.

Chinn TJ. 1980. Glacier balances in the Dry Valleys area, Victoria Land, Antarctica. International Association of Hydrological Sciences 126: 
237-247.

1981. Hydrology and climate in the Ross Sea area. Journal of the Royal Society of New Zealand 11: 373-386.

1990. The dry valleys in Antarctica: The Ross Sea region. Wellington (New Zealand): Department of Scientific and Industrial Research. 1993. Physical hydrology of the Dry Valley lakes. Pages 1-52 in Green WJ, Friedmann EI, eds. Physical and Biological Processes in Antarctic lakes. Antarctic Research Series, Vol. 59. Washington (DC): American Geophysical Union.

Clow GD, McKay CP, Simmons GM Jr, Wharton RA Jr. 1988. Climatological observations and predicted sublimation rates at Lake Hoare, Antarctica. Journal of Climate 1: 715-728.

Conovitz PA, McKnight DM, McDonald LM, Fountain AG, House HR. 1998. Hydrologic processes influencing streamflow variations in Fryxell Basin, Antarctica. Pages 93-108 in Priscu JC, ed. Ecosystem Dynamics in a Polar Desert: The McMurdo Dry Valleys, Antarctica. Antarctic Research Series, Vol. 72. Washington (DC): American Geophysical Union.

Dana GL, Wharton RA Jr, Dubayah R. 1998. Solar radiation in the McMurdo Dry Valleys, Antarctica. Pages 39-65 in Priscu JC, ed. Ecosystem Dynamics in a Polar Desert: The McMurdo Dry Valleys, Antarctica. Antarctic Research Series, Vol. 72. Washington (DC): American Geophysical Union.

Denton GH, Brockheim JG, Wilson SC, Stuiver M. 1989. Late Wisconsin and early Holocene glacial history, inner Ross embayment, Antarctica. Quaternary Research 31: 151-182.

Doran PT, Wharton RA Jr, Lyons WB. 1994. Paleolimnology of the McMurdo Dry Valleys, Antarctica. Journal of Paleolimnology 10: 85-114.

Downes MT, Howard-Williams C, Vincent WF. 1986. Source of organic nitrogen, phosphorus and carbon in Antarctic streams. Hydrobiologia 134: 215-225.

Fountain AG, Dana GL, Lewis KJ, Vaughn BL, McKnight DM. 1998. Glaciers of the McMurdo Dry Valleys, Southern Victoria Land, Antarctica. Pages 65-76 in Priscu JC, ed. Ecosystem Dynamics in a Polar Desert: The McMurdo Dry Valleys, Antarctica. Antarctic Research Series, Vol. 72. Washington (DC): American Geophysical Union.

Fountain AG, Lewis KJ, Doran P. In press. Spatial climatic variation and its control on glacier equilibrium line altitude in Taylor Valley, Antarctica. Global and Planetary Change.

Freckman DW. 1986. The ecology of dehydration in soil organisms. Pages 157-168 in Leopold AC, ed. Membranes, Metabolism and Dry Organisms. Ithaca (NY): Cornell University Press.

Freckman DW, Virginia RA. 1997. Low-diversity Antarctic soil nematode communities: Distribution and response to disturbance. Ecology 78: 363-369.

Friedmann EI. 1982. Endolithic microorganisms in the Antarctic cold desert. Science 215: 1045-1053.

Fritsen CH, Priscu JC. 1999. Seasonal change in optical properties of the permanent ice cover on Lake Bonney, Antarctica: Consequences for lake productivity and phytoplankton dynamics. Limnology and Oceanography 44: 447-454.

Fritsen CH, Adams EE, McKay CM, Priscu JC. 1998. Permanent ice covers of the McMurdo Dry Valley Lakes, Antarctica: Liquid water content. Pages 269-280 in Priscu JC, ed. Ecosystem Dynamics in a Polar Desert: The McMurdo Dry Valleys, Antarctica. Antarctic Research Series, Vol. 72. Washington (DC): American Geophysical Union.

Hall BL, Denton GH, Lux DR, Bockheim JG. 1993. Late Tertiary Antarctic paleoclimate and ice-sheet dynamics inferred from surficial deposits in Wright Valley. Geografiska Annalar 75A: 239-268.

Hendy CH, Healy TR, Rayner EM, Shaw J, Wilson AT. 1979. Late Pleistocene glacial chronology of the Taylor Valley, Antarctica, and the global climate. Quaternary Research 11: 172-184.

Howard-Williams C, Schwarz A, Hawes I, Priscu JC. 1998. Optical properties of lakes of the McMurdo Dry Valleys. Pages 189-204 in Priscu JC, ed. Ecosystem Dynamics in a Polar Desert: The McMurdo Dry Valleys, Antarctica. Antarctic Research Series, Vol. 72. Washington (DC): American Geophysical Union.
James M, Hall J, Laybourn-Parry J. 1998. Protozooplankton and microzooplankton ecology in lakes of the dry valleys southern Victoria Land. Pages 255-268 in Priscu JC, ed. Ecosystem Dynamics in a Polar Desert: The McMurdo Dry Valleys, Antarctica. Antarctic Research Series, Vol. 72. Washington (DC): American Geophysical Union.

Kennedy AD. 1993. Water as a limiting factor in the Antarctic terrestrial environment: A biogeographical synthesis. Arctic and Alpine Research 25: 308-315.

Kepner R, Galchenko V, Wharton RA Jr. 1997. The abundance of planktonic viruses in Antarctic lakes. Pages 241-252 in Lyons WB, HowardWilliams C, Hawes I, eds. Ecosystem Processes in Antarctic Ice-Free Landscapes. Rotterdam (The Netherlands): A. A. Balkema.

Kepner R, Wharton RA Jr, Suttle CA. 1998. Viruses in Antarctic lakes. Limnology and Oceanography 43: 1754-1761.

Kepner R, Coats DW, Wharton RA Jr. 1999. Ciliated protozoa of two Antarctic lakes: Analysis by quantitative protargol staining and examination of artificial substrates. Polar Biology 21: 285-294.

Keys JR. 1980. Air Temperature, Wind, Precipitation and Atmospheric Humidity in the McMurdo Region. Wellington (New Zealand): Geology Department, Victoria University. Publication no. 17.

Laybourn-Parry J, James M, McKnight D, Priscu JC, Spaulding S, Shiel R. 1997. The microbial plankton of Lake Fryxell, Southern Victoria Land, Antarctica, during the summers of 1992 and 1994. Polar Biology 17: $54-61$.

Lewis KJ, Fountain AG, Dana GL. 1998. Energy balance studies of Canada Glacier, Taylor Valley, McMurdo Dry Valleys, Antarctica. Annals of Glaciology 27: 603-609.

Lewis KJ, Fountain AG, Langevin PL. In press. The importance of terminus cliff melt on stream flow, Taylor Valley, McMurdo Dry Valleys. Global and Planetary Change.

Lizotte MP, Priscu JC. 1992. Photosynthesis-irradiance relationships in phytoplankton from Lake Bonney, a perennially ice-covered lake (Antarctica). Journal of Phycology 28: 179-185.

1998. Distribution, succession and fate of phytoplankton in the McMurdo Dry Valley Lakes of Antarctica, based on pigment analysis. Pages 229-240 in Priscu JC, ed. Ecosystem Dynamics in a Polar Desert: The McMurdo Dry Valleys, Antarctica. Antarctic Research Series, Vol. 72. Washington (DC): American Geophysical Union.

Lyons WB, Mayewksi PA, Bartek LR, Doran PT. 1997. Climate history of the McMurdo Dry Valleys since the last glacial maximum: A synthesis. Pages 15-22 in Lyons WB, Howard-Williams C, Hawes I, eds. Ecosystem Processes in Antarctic Ice-Free Landscapes. Rotterdam (The Netherlands): A. A. Balkema.

Lyons WB, Welch KA, Neumann K, Toxey JK, McArthur R, Williams C, McKnight DM, Moorhead DL. 1998a. Geochemical linkages among glaciers, streams and lakes within the Taylor Valley, Antarctica. Pages 77-92 in Priscu JC, ed. Ecosystem Dynamics in a Polar Desert: The McMurdo Dry Valleys, Antarctica. Antarctic Research Series, Vol. 72. Washington (DC): American Geophysical Union.

Lyons WB, Tyler SW, Wharton RA Jr, McKnight DM, Vaughn BH. 1998b. A late Holocene desiccation of Lake Hoare and Lake Fryxell, McMurdo Dry Valleys, Antarctica. Antarctic Science 10: 247-256.

Lyons WB, Frape SK, Welch KA. 1999. History of McMurdo Dry Valley lakes, Antarctica, from stable chlorine data. Geology 27: 527-530.

Marchant DR, Denton GH. 1996. Miocene and Pliocene paleoclimate of the Dry Valley region, southern Victoria Land: A geomorphological approach. Marine Micropaleontology 27: 253-271.

Matsubaya O, Sakai H, Torii T, Burton H, Kerry K. 1979. Antarctic saline lakes-stable isotopic ratios, chemical compositions and evolution. Geochimica et Cosmochimica Acta 43: 7-25.

Mayewski PA, et al. 1995. An ice-core-based, Late Holocene history for the Transantarctic Mountains, Antarctica. Pages 33-45 in Elliot DH, Blaisdell GL, eds. Contributions to Antarctic Research IV. Antarctic Research Series, Vol. 67. Washington (DC): American Geophysical Union.

McKay CP, Melln MT, Friedmann EI. 1998. Soil temperatures and stability of ice-cemented ground in the McMurdo Dry Valleys, Antarctica. Antarctic Science 10: 31-38.

McKelvey BC. 1982. Late Cenozoic marine and terrestrial glacial sedimen- 
tation in eastern Taylor Valley, Southern Victoria Land. Pages 1109-1116 in Craddock C, ed. Antarctic Geoscience. Madison (WI): University of Wisconsin Press. Series B, International Union of Geological Sciences, number 4.

McKnight DM, Tate CM. 1997. Canada stream: A glacial meltwater stream in Taylor Valley, South Victoria Land, Antarctica. Journal of the North American Benthological Society 16: 14-17.

McKnight DM, Alger A, Tate CM, Shupe G, Spaulding S. 1998. Longitudinal patterns in algal abundance and species distribution in meltwater streams in Taylor Valley, Southern Victoria Land, Antarctica. Pages 109-128 in Priscu JC, ed. Ecosystem Dynamics in a Polar Desert: The McMurdo Dry Valleys, Antarctica. Antarctic Research Series, Vol. 72. Washington (DC): American Geophysical Union.

McKnight DM, Niyogi DK, Alger AS, Bomblies A, Conovitz PA, Tate CM. 1999. Dry valley streams in Antarctica: Ecosystems waiting for water. BioScience 49: 985-995.

Miller MF, Mabin MCG. 1998. Antarctic neogene landscapes-in the refrigerator or in the deep freeze? Geological Society of America Today 8(4): 1-3.

Moorhead DL, Priscu JP. 1998. The McMurdo Dry Valley ecosystem: Organization, controls, and linkages. Pages 351-354 in Priscu JC, ed. Ecosystem Dynamics in a Polar Desert: The McMurdo Dry Valleys, Antarctica. Antarctic Research Series, Vol. 72. Washington (DC): American Geophysical Union.

Moorhead DL, Doran PT, Fountain AG, Lyons WB, McKnight DM, Priscu JC, Virginia RA, Wall DH. 1999. Ecological legacies: Impacts on ecosystems of the McMurdo Dry Valleys. BioScience 49: 1009-1019.

Morgan RM, Ivanov AG, Priscu, JC Maxwell DP, Huner NPA. 1998. Structure and composition of the photochemical apparatus of the Antarctic green alga, Chlamydomonas subcaudata. Photosynthesis Research 56: 303-314.

Mulvaney R, Wolff EW. 1994. Spatial variability of the major chemistry of the Antarctic ice sheet. Annals of Glaciology 20: 440-447.

Neale PJ, Priscu JC. 1998. Fluorescence quenching in phytoplankton of the McMurdo Dry Valley lakes (Antarctica): Implications for the structure and function of the photosynthesis apparatus. Pages 241-254 in Priscu JC, ed. Ecosystem Dynamics in a Polar Desert: The McMurdo Dry Valleys, Antarctica. Antarctic Research Series, Vol. 72. Washington (DC): American Geophysical Union.

Powers LE, Freckman DW, Virginia RA. 1994. Survival of Scottnema lindsayae under extreme osmotic conditions. Journal of Nematology 26: 116-118.

Priscu JC. 1991. Variation in light attenuation by the permanent ice cap of Lake Bonney during spring and summer. Antarctic Journal of the Unit- ed States 26: 223-225.

1995. Phytoplankton nutrient deficiency in lakes of the McMurdo Dry Valleys, Antarctica. Freshwater Biology 34: 215-227.

1997. The biogeochemistry of nitrous oxide in permanently icecovered lakes of the McMurdo Dry Valleys, Antarctica. Global Change Biology 3: 301-305.

Priscu JC, Fritsen CH, Adams EE, Giovannoni SJ, Paerl HW, McKay CP, Doran PT, Gordon DA, Lanoil BD, Pinckney JL. 1998. Perennial Antarctic lake ice: An oasis for life in a polar desert. Science 280: 2095-2098.

Priscu JC, Wolf CF, Takacs CD, Fritsen CH, Laybourn-Parry J, Roberts EC, Sattler B, Lyons WB. 1999. Carbon transformations in a perennially ice-covered Antarctic lake. BioScience 49: 997-1008.

Roberts EC, Laybourn-Parry J. 1999. Mixotrophic cryptophytes and their predators in the dry valley lakes of Antarctica. Freshwater Biology 41: 737-745.

Seaburg KG, Kasper M, Parker BC. 1983. Photosynthetic quantum efficiencies of phytoplankton from perennially ice-covered Antarctic lakes. Journal of Phycology 19: 446-452.

Smith RC, et al. 1999. Marine ecosystem sensitivity to climate change. BioScience 49: 393-404.

Stuiver M, Denton GH, Hughes TJ, Fastook JL. 1981. History of the marine ice sheet in West Antarctica during the last glaciation: A working hypothesis. Pages 319-436 in Denton GH, Hughes TH, eds. The Last Great Ice Sheets. New York: Wiley Interscience.

Swanson FJ, Kratz TK, Caine N, Woodmansee RG. 1988. Landform effects on ecosystem patterns and processes. BioScience 38: 92-98.

Vincent WF. 1988. Microbial Ecosystems of Antarctica. Cambridge (UK): Cambridge University Press.

Webster JR, Meyer J. 1997. Stream organic matter budgets. Journal of the North American Benthological Society 16: 31-61.

Welch KA. 1993. Glaciochemical investigations of the Newall Glacier, Southern Victoria Land, Antarctica. Master's thesis. University of New Hampshire, Durham, NH.

Wharton RA Jr, Parker BC, Simmons GM Jr. 1983. Distribution, species composition, and morphology of algal mats in Antarctic dry valley lakes. Phycologia 23: 355-365.

Wharton RA Jr, McKay CP, Simmons GM Jr, Parker BC. 1985. Cryoconite holes on glaciers. BioScience 35: 499-503.

Wilch TR, Denton GH, Lux DR, McIntosh WC. 1993. Limited Pliocene glacier extent and surface uplift in Middle Taylor Valley, Antarctica. Geografiska Annalar 75A: 331-351.

Wilson AT. 1964. Evidence from chemical diffusions of a climate change in the McMurdo Dry Valleys 1200 years ago. Nature 201: 176-177. 